\title{
CAN INVESTING DIARIES BE HAZARDOUS TO YOUR FINANCIAL HEALTH?
}

\author{
Michael C. Cipriano \\ Associate Professor of Accounting, \\ St Ambrose University
}

\author{
Thomas S. Gruca \\ Tippie Professor of Marketing \\ University of Iowa
}

\author{
Jinfeng (Jenny) Jiao \\ Assistant Professor of Marketing, Binghamton University
}

\begin{abstract}
Business writers and academics have suggested keeping an investing diary to avoid hindsight bias. In the diary, investors justify their predictions of future events, e.g., "This stock will go up because..." Eliminating hindsight bias should improve future returns. However, psychological research on the "explanation effect" suggests that justifying one's predictions in writing induces overconfidence and, by consequence, reduces current returns. We test these propositions in a set of prediction markets populated by two types of traders: forecasters who completed a required investing diary task and non-forecasters who did not. The portfolios of forecasters were significantly over-invested in securities associated with the forecaster's prediction. This is consistent with prior psychological research and a clear sign of investor over-confidence. We further find that forecasters with accurate predictions have higher returns than those with inaccurate predictions. However, the returns for forecasters with inaccurate predictions were generally no worse than the returns of the nonforecasters. Our results suggest that while keeping an investing diary may lead to biased portfolios, it does not have an overall negative effect on current returns. Therefore, contrary to expectations, there is not a trade-off between the longterm and short-term effects of an investing diary.
\end{abstract}

\section{INTRODUCTION}

In recent decades, the retirement plans of many Americans have transitioned from a professionally managed defined benefit plan to an individually guided defined contribution model (Elkins, 2017). This trend, along with the development of online stock trading for individuals (Barber and Odean, 2002), means that more people than ever are responsible for their own investment decisions (van Raaij, 2014). The involvement of non-professionals in selfmanaged investing may be problematic since most consumers have little formal training in financial analysis or investing. Moreover, the behavioral finance literature suggests that financial decision-making in general is subject to a 
range of biases and decision traps that can negatively affect returns (Barberis and Thaler, 2001). Resulting investing errors can have negative consequences for workers before and after retirement.

Reflecting this concern, academics in accounting have begun a stream of research on the impact of various biases on the judgments of non-professional investors (Eames, Glover, Kennedy, 2006; Hales, 2007; Han and Tan, 2010; Thayer, 2011). At the same time, the popular business press has responded with a number of books discussing various biases and providing advice on how to avoid them (e.g. Belsky and Gilovich, 2000; Montier, 2010; Thaler, 2015).

A very common decision trap is "hindsight bias," also known as the "knewit-all-along" effect. This bias occurs when people overestimate their ability to have predicted an outcome after it has already occurred. This bias occurs since humans are very good at integrating new information into their existing knowledge base (Roese and Vohs, 2012). For example, once we know an outcome (e.g., what happened to a given stock), it is very difficult to accurately recall our ex ante forecast of the observed outcome since one's knowledge has been effectively updated (Erdfelder and Buchner, 1998; Hawkins and Hastie, 1990). Therefore, hindsight bias leads investors to be overconfident because they think they had accurately predicted past events (Granhag, Stromwall and Allwood, 2000; Zweig, 2007). Such overconfidence is predicted to lead investors to ignore important new information (Daniel, Hirshleifer and Subramanyam, 1998; Gervais and Odean, 2001), have lower perceptions of risk (Moore and Healy, 2008), build less diversified portfolios (Odean, 1998), etc. All of these effects may lead to poor investment outcomes (Biasis and Weber, 2009).

While psychologists have proposed numerous approaches to avoid hindsight bias, almost all of them fail (e.g., Fischoff 1977; Wood 1978; Pohl and Hell 1996). Consequently, many researchers conclude that relying on memory itself is the source of hindsight bias (Hawkins and Hastie, 1990). Therefore, to help eliminate hindsight bias, both academics (e.g. Baruch Fischoff quoted in Zweig, 2007) and popular business authors (Hens and Maier, 2016; Constable, 2016; Hoffman, 2015; Lim and Cheong, 2017) suggest that investors should keep an "investing diary." In this written record, investors should write down their forecasts of the future as well as the reasons they invest in a particular stock or other security before they invest. In the future, the investor will not have to rely on their faulty memories, eliminating the major source of hindsight bias. Thus, keeping an investing diary should improve an investor's future financial decision-making.

However, a long stream of research in psychology suggests that the process of recording one's predictions of the future and accompanying justifications may introduce a different bias - confirmation bias - that can negatively affect current financial outcomes. Research on the "explanation effect" suggests that very act of explaining the reasons for one's beliefs about a future event increases your judgment of the likelihood of that event (Ross, Lepper, Strack and Steinmetz, 1977) and negatively affects how you process new, especially 
contradictory, information, regarding the event (Anderson, Lepper and Ross, 1980). Both of these effects result in investor over-confidence, which theoretical models have shown to hurt financial outcomes (Daniel, et al., 1998; Odean, 1998; Rabin and Schrag, 1999).

We test this conjecture in a set of real money prediction markets with two important features. First, in each market, a subset of traders completes a required "investing diary"-like task before the market opens for trading. In this task, these traders (hereafter known as "forecasters") provide a written justification for their forecast of a future event (Other traders in the market - "non-forecasters" - are not required to submit a forecast or justification). Prior research on the impact of the explanation effect on traders was limited to prediction markets where all participants were forecasters (Goins, Cipriano and Gruca, 2015). Having a pool of forecasters and non-forecasters in the same market allows for testing of the impact of the investing diary task on trader returns.

Second, both the forecasters and non-forecasters participate trade in a realmoney prediction market where the values of securities are determined by the same outcome that the traders in the forecasters group sought to predict. This type of security creates a linkage between a forecaster's preference for a given outcome and their preference for a given security (assuming a positive preference for money). This feature of the prediction market securities allows us to test the impact of the investing diary task on the portfolio holdings of those in the forecasters group.

Our two hypotheses focus on the effects of over-confidence stemming from the explanation effect. First, due to overconfidence induced by the investing diary task, forecasters will over-invest in securities that are consistent with their preferred outcome. Second, if a trader's initial forecast is inaccurate, it is rational to change one's mind and portfolio to accommodate new information. However, traders who have completed the required investing diary task may ignore new value-relevant information that is inconsistent with their initial predictions (Bodenhausen, 1988; Nickerson, 1998). Both theoretical models (Schredelseker, 1984) and experimental studies (Huber, 2007) suggest that forecasters with inaccurate predictions will have returns lower than those of the non-forecasters.

To test these hypotheses, we used data from the Iowa Electronic Market, a small-scale, real money prediction market. Four prediction markets (conducted between 1999 and 2002) were designed to forecast a movie's box office receipts. In each market, several securities were offered, the value of which was tied to a specific level of box office performance. A subset of the traders were required (as part of a class assignment) to complete an investing diary-like task. These forecasters generated a written forecast (and justification) of the specific movie's future box office performance that was submitted before any trading commenced. The traders in the non-forecasters group were considered presumptively unbiased by the explanation effect associated with the investing diary task. 
We compared holdings in preferred outcome securities of forecasters relative to non-forecasters and found significantly higher holdings in the preferred outcome contracts. Thus, we find that the investing diary task resulted in unbalanced portfolios, a finding consistent with our first hypothesis and, importantly, prior theoretical models of investor over-confidence (Odean, 1998).

Second, in three of the four markets, we found that forecasters with accurate predictions had higher returns than forecasters with inaccurate predictions. However, in only one market did we find that non-forecasters had higher returns than inaccurate forecasters. Thus, we fail to find strong support for the findings of prior research on a J-shaped relationship between information asymmetry across traders and returns. Therefore, our results suggest that the basic elements of an investing diary lead investors to exhibit overconfidence which impacts investing actions (as reflected in portfolio holdings) but they have limited effect on investing outcomes.

The rest of the paper proceeds as follows: Section 2 describes the prior literature related to hindsight bias, the explanation effect, overconfidence and our hypotheses. Section 3 provides background information on our markets and our market timeline. Section 4 focuses on the formulations of the models we used to test our two hypotheses. In Section 5, we present our results. Section 6 concludes with a discussion of our findings and directions for future research.

\section{PREVIOUS LITERATURE AND HYPOTHESIS DEVELOPMENT}

\subsection{HINDSIGHT BIAS AND INVESTING DIARIES}

Hindsight bias is well-studied, having been the subject of some 800 academic papers (Roese and Vohs, 2012). Hindsight bias affects judgments in many fields including politics (Carey, 2012; Blank, Fischer and Erdfelder, 2003) and medicine (Hugh and Tracy, 2002; Arkes, 2013). A study of investment bankers found that those with higher levels of hindsight bias earned significantly less money (Biasis and Weber, 2009).

Hindsight bias has multiple aspects including distortions of memory, biased beliefs about an event's objective likelihood and an inflated sense of one's own forecasting abilities (Roese and Vohs, 2012). Of its various negative effects, the sense of "overconfidence in the certainty of one's judgments" (Roese and Vohs, 2012, p. 411) has particular relevance for financial decision-making given the stream of research showing the negative impacts of overconfidence on investors (Odean, 1998) and markets (Daniel, et al. 1998) alike.

Despite the numerous interventions studied in the psychology literature, it is very difficult to eliminate hindsight bias (e.g., Fischoff, 1977; Wood, 1978; Pohl and Hell, 1996). This challenge has convinced some researchers that the source of hindsight bias lies in, "the process by which information is integrated and retrieved in a person's mind," (Christensen-Szalanski and 
Fobian-Willham, 1991, p. 148). Since these processes are not under conscious control, they are hard to alter. Therefore, to avoid relying on a person's potentially flawed memory, Davies (1987) supplied subjects with notes they used in an initial judgement phase. This written information all but eliminated hindsight bias in a subsequent judgment task. The successful de-biasing experiment by Davies (1987) provides concrete empirical support of the idea of using an investing diary to avoid hindsight bias.

Investing diaries are recommended by both financial writers (Constable, 2016; Hoffman, 2015; Lim and Cheong, 2017) and academics (Zweig, 2007). The essential task for investors is to write down the reasons they invest in a particular stock or other security before they invest. In the book, Your Money and Your Brain, psychologist Baruch Fischhoff is quoted as suggesting that investors keep a diary to document their reasons for investing before they buy (Zweig 2007: pages 67-68). An investor should, "(k)eep a record of what was on your mind when you made predictions." Investors should be able to answer the question, "I think this investment will go up because..."

By having written records, investors will not have to rely on their potentially faulty memories of the past. Since investors will avoid improperly recalling their past reasoning, they will be less likely to develop an unjustifiably positive opinion of their forecasting prowess. By eliminating hindsight bias as a source of future over-confidence, an investing diary should improve future financial decision-making. However, the process of making a forecast of the future and justifying it in writing - the basic parts of an investing diary entry - can introduce confirmation bias due to the explanation effect. As we discuss in the next section, the explanation effect can lead to investor over-confidence to the detriment of current financial returns.

\subsection{THE EXPLANATION EFFECT}

Numerous studies in psychology suggest that the act of explanation has a consistent impact on an individual's beliefs about the future, use of new information and future behavior. Individuals who provided an explanation for a future event judged its likelihood significantly higher than those who did not provide an explanation (Ross, et al., 1977) or those whose explanation supported a different outcome (Sherman, Zehner, Johnson and Hirt, 1983). In addition, individuals who created written explanations are more likely to persist in their beliefs despite disconfirming evidence than those who have not developed a written explanation (Anderson, et al., 1980). An explanation task can affect more than beliefs; in some circumstances, it can alter future behavior (e.g. Sherman, 1980; Sherman, Skov, Hervitz and Stock, 1981) as well.

When keeping an investing diary, an investor writes down a forecast of the future ("I believe this stock will go up") and a written justification for that forecast. The extant research cited above suggests that writing down and justifying a forecast will result in an increased belief, on the part of the 
investor, in the outcome recorded in the diary. In the case of a prediction market, an investing diary entry would increase the trader's belief in the likelihood of the predicted outcome. Given a positive utility for money, a trader with an investing diary should prefer the specific security associated with the predicted outcome to finish "in the money." Therefore, we expect that prediction market traders who completed an investing diary task are likely to over-invest in the security associated with their forecasted outcome. This leads to our first hypothesis:

Hypothesis 1 (H1): Traders who have completed an investing diary task will hold a higher proportion of the security associated with their preferred outcome than other traders.

One cognitive theory supporting the explanation effect is the "availability of causal representations" heuristic (Ross and Sicoly, 1982; Hammersley, Kadous, and Magro, 1997). Studies of causal representation find that information that is more consistent with a subject's initial explanation receives more weight in subsequent assessments of the likelihood that the forecasted event will happen. Inconsistent information will either receive less weight or be completely ignored (e.g. Ditto, Munro, Apanovitch, Scepansky and Lockhart, 1998; Lord, Lepper and Ross, 1979). Therefore, the written explanation induces the kind of confirmation bias described by Nickerson (1998) and shown to manifest into negative returns for investors by Daniel et al. (1998), Rabin and Schrag (1999) and Pouget, Sauvagnat and Villeneuve (2014). Specifically, there will be biased assimilation of new, value-relevant information.

We expect that once the prediction market opens, forecasters (those who completed an investing diary task) will ignore useful information that is inconsistent with their initial predictions and continue to buy and/or hold securities that are consistent with their initial predictions. However, the ultimate impact of the investing diary task on returns depends on the accuracy of the forecaster's initial prediction. Prior research using prediction markets suggests that forecasters with accurate predictions have higher returns despite the presence of confirmation bias (Goins, et al. 2015). These results are limited since they come from prediction markets in which all traders are subject to confirmation bias. In the markets studied here, there is a mixture of forecasters who were required to complete the investing diary task and non-forecasters who were not.

How these non-forecasters would affect a prediction market is not certain. On the one hand, the non-forecasters may be considered uninformed "noise" traders who merely provide liquidity to the market (Wolfers and Zitzewitz, 2004). On the other hand, the non-forecasters may be considered unbiased or "rational" traders compared to the group of forecasters (Odean 1998). Prior prediction market research on price changes associated with value relevant information favors this latter view (Goins, et al., 2015). 
To understand the returns of non-forecasters compared to the forecasters, we turn to the experimental research on the effect of asymmetric information on returns (Huber, 2007; Huber, Kirckler and Sutter, 2008; Huber, Angerer and Kirchler, 2011; Kirchler, 2010). Complete information (e.g., a correct forecast), of course, should result in the highest returns (Grossman and Stiglitz, 1980). The surprising result from these experiments is that uninformed traders can have higher returns than those with intermediate levels of information (Huber, 2007).

In these lab experiments, the varied information levels were assigned randomly. Those traders without any information trade in an almost random manner, resulting in returns at the market average (Huber, et al., 2011). Of course, those traders with full information leverage this advantage to their benefit. The question is: Why do traders with intermediate levels of information have returns equal to or lower than traders with no information? One answer supplied by Kirchler (2010) is that these traders rely on their incomplete information to their detriment in trading with better informed "insiders."

In our study, we are unaware of the private information brought to the market by non-forecasters. However, with respect to the group of forecasters, we can identify those who are ex post completely informed (i.e., have accurate forecasts) and those who are only partially informed (i.e., have inaccurate forecasts). Based on this classification on forecasters and the prior research cited above, we expect that forecasters with accurate forecasts will have the highest returns followed by the non-forecasters. Due to confirmation bias, forecasters with inaccurate predictions will ignore new value-relevant information. This will result in the lowest returns of all. This leads to our second hypothesis:

Hypothesis 2 (H2): Traders who have completed an investing diary task and have inaccurate forecasts will generate lower average returns than traders who did not complete an investing diary task.

The J-shaped relationship between information levels and returns was documented in lab experiments (Huber, 2007). However, variations in information across trader were randomly assigned and common knowledge. In our prediction markets, traders have different levels of accuracy but whether they are well-informed or not is only known ex post. Since we relax two of the important limitations of the lab experiments, our study also serves as a test of whether the observed J-shaped pattern is robust to these more realistic conditions.

\section{STUDY SETTING}

This study utilizes the Iowa Electronic Market, a small-scale, real-money prediction market. It is best known for producing accurate forecasts of election 
outcomes (Forsythe, Nelson, Neumann and Wright, 1992; Berg, Nelson, Rietz, 2008). All trading is conducted via an anonymous, computerized double auction that accepts both market and limit orders. All limit orders (bids/asks) are queued by price and submission times. The best bid and ask prices are available to traders as are past daily average prices and transaction levels. An individual's initial investment in the market is limited to \$500 and no short selling is allowed. In addition, no transactions fees are charged to traders.

Investors may acquire securities from the market in a bundle consisting of one of each of the securities in the market. A complete bundle of securities may be purchased from or sold to the exchange at any time for $\$ 1$, the guaranteed liquidation value of the bundle. Therefore, the supply of securities in the market expands and shrinks as investors desire without affecting the individual prices as set by the investors.

\subsection{MOVIE BOX OFFICE MARKETS}

We focus on a set of 4 markets that were intended to predict the 4-week domestic box office performance of a particular movie. As shown in Table 1, the movies (and release year in parentheses) were Sleepy Hollow (1999), The World is Not Enough (1999), Harry Potter and the Sorcerer's Stone (2001), and Die Another Day (2002). Trading in the movie markets began 14 days before the opening of the movie in theaters. Investors could access the market 24-hours a day through the Internet. Trading continued for four weeks after the opening of the movie. The securities were liquidated after official four-week box office data became available.

Table 1 - Movie Markets Overview

\begin{tabular}{|l|l|l|l|l|}
\hline Movie & $\begin{array}{l}\text { Sleepy } \\
\text { Hollow (SH) }\end{array}$ & $\begin{array}{l}\text { The World Is } \\
\text { Not Enough } \\
\text { (WINE) }\end{array}$ & $\begin{array}{l}\text { Harry Potter and } \\
\text { the Sorcerer's } \\
\text { Stone (HPS) }\end{array}$ & $\begin{array}{l}\text { Die Another } \\
\text { Day (DIE) }\end{array}$ \\
\hline $\begin{array}{l}\text { Date market } \\
\text { opened }\end{array}$ & $11 / 5 / 1999$ & $11 / 5 / 1999$ & $11 / 2 / 2001$ & $11 / 8 / 2002$ \\
\hline $\begin{array}{l}\text { Date movie opened } \\
\text { in theaters }\end{array}$ & $11 / 19 / 1999$ & $11 / 19 / 1999$ & $11 / 16 / 2001$ & $11 / 22 / 2002$ \\
\hline Date market closed & $12 / 16 / 1999$ & $12 / 16 / 1999$ & $12 / 13 / 2001$ & $12 / 16 / 2002$ \\
\hline $\begin{array}{l}\text { Number of } \\
\text { contracts }\end{array}$ & 5 & 5 & $6^{*}$ & 5 \\
\hline
\end{tabular}

*As noted in Footnote 1, one of the securities (HPS220H) was split into two securities (HPS240L and HPS240H) to promote trading activity. Analysis was adjusted accordingly and trading activity in the HPS market was consistent with activity in other markets examined in this study. 
In each market, a bundle of 5 securities was offered. ${ }^{1}$ Each security is associated with a mutually exclusive and collectively exhaustive range of box office receipts within the specified four-week period. For example, in the 1999 market for the movie, Sleepy Hollow, a security denoted as SH030L paid \$1 if the 4 week box office performance was $\$ 30$ million or less. It paid $\$ 0$ otherwise. The SH050L security paid $\$ 1$ for receipts greater than $\$ 30$ million but less than or equal to $\$ 50$ million, zero otherwise. All securities are similarly designed.

\subsection{TRADERS}

Certain traders, as part of a graduate business class assignment, were required to submit a forecast of the 4-week box office performance for each movie supported by a 2-4 page justification of their forecasts. An example of the task assignment may be found in Gruca (2000). In exchange for their forecasts and accompanying written justifications, forecasters were provided a $\$ 10$ trading account (They could add more funds up to the $\$ 500$ initial investment limit). They were also asked to execute at least two trades while the market was open (buying or selling a bundle of securities is considered a trade).

Participation in these four prediction markets was open to all IEM traders with an academic affiliation. The traders that were not required to complete the investing diary task are classified as non-forecasters. The number of traders in each group as well as trading activity are presented in Table 2 .

There were a total of 351, 302, 381 and 180 traders in the Sleepy Hollow (1999), The World is Not Enough (1999), Harry Potter (2001) and Die Another Day (2002) markets, respectively. While the majority of traders are nonforecasters, the amount of buy trades and amounts invested in each market are quite similar for both groups. On average, the two groups appear to be similarly engaged in trading.

\subsection{MARKET TIMELINE}

All of the investing diary tasks were completed (and submitted) before the markets opened for trading. A market timeline is presented in Figure 1.

For these markets, Nielsen/EDI (entdata.com) provided official results of box office performance on a weekly basis. Daily estimates were also available

\footnotetext{
${ }^{1}$ In the Harry Potter and the Sorcerer Stone (HPS) market, one of the 5 securities was split prior to movie open in light of sluggish market activity up to that point. This created a 6-security market from the split date (November 12, 2001) through the end of the market. This decision to promote trading does not appear to have any bearing on our hypothesis tests as the data from the HPS market is highly consistent with the data gathered in the other markets examined in this paper.
} 
Table 2. Market Activity

\begin{tabular}{|c|c|c|c|}
\hline & Forecasters & Non-Forecasters & Total \\
\hline \multicolumn{4}{|l|}{ Sleepy Hollow (1999) } \\
\hline Traders & 89 & 262 & 351 \\
\hline Number of Buy Trades & 1,229 & 984 & 2,213 \\
\hline Number of securities bought & 9,587 & 8,580 & 18,167 \\
\hline Transaction Volume in Dollars & $\$ 1,786.16$ & $\$ 1,830.66$ & $\$ 3,616.82$ \\
\hline Funds Invested Per Trader & $\$ 20.07$ & $\$ 6.99$ & \\
\hline \multicolumn{4}{|l|}{ The World in Not Enough (1999) } \\
\hline Traders & 92 & 210 & 302 \\
\hline Number of Buy Trades & 1,094 & 1,076 & 2,170 \\
\hline Number of securities bought & 9,744 & 11,177 & 20,921 \\
\hline Transaction Volume in Dollars & $\$ 1,850.31$ & $\$ 2,358.61$ & $\$ 4,208.92$ \\
\hline Funds Invested Per Trader & $\$ 25.69$ & $\$ 8.74$ & \\
\hline \multicolumn{4}{|l|}{ Harry Potter (2001) } \\
\hline Traders & 107 & 274 & 381 \\
\hline Number of Buy Trades & 1,350 & 1,343 & 2,693 \\
\hline Number of securities bought & 5,547 & 4,597 & 10,144 \\
\hline Transaction Volume in Dollars & $\$ 1,170.08$ & $\$ 1,391.36$ & $\$ 2,561.44$ \\
\hline Funds Invested Per Trader & $\$ 10.91$ & $\$ 5.09$ & \\
\hline \multicolumn{4}{|l|}{ Die Another Day (2002) } \\
\hline Traders & 81 & 99 & 180 \\
\hline Number of Buy Trades & 934 & 985 & 1,919 \\
\hline Number of securities bought & 4,375 & 12,158 & 16,533 \\
\hline Transaction Volume in Dollars & $\$ 746.92$ & $\$ 2,393.03$ & $\$ 3,139.95$ \\
\hline Funds Invested Per Trader & $\$ 9.22$ & $\$ 24.17$ & \\
\hline
\end{tabular}

Figure 1. Movie Box Office Market Time Line

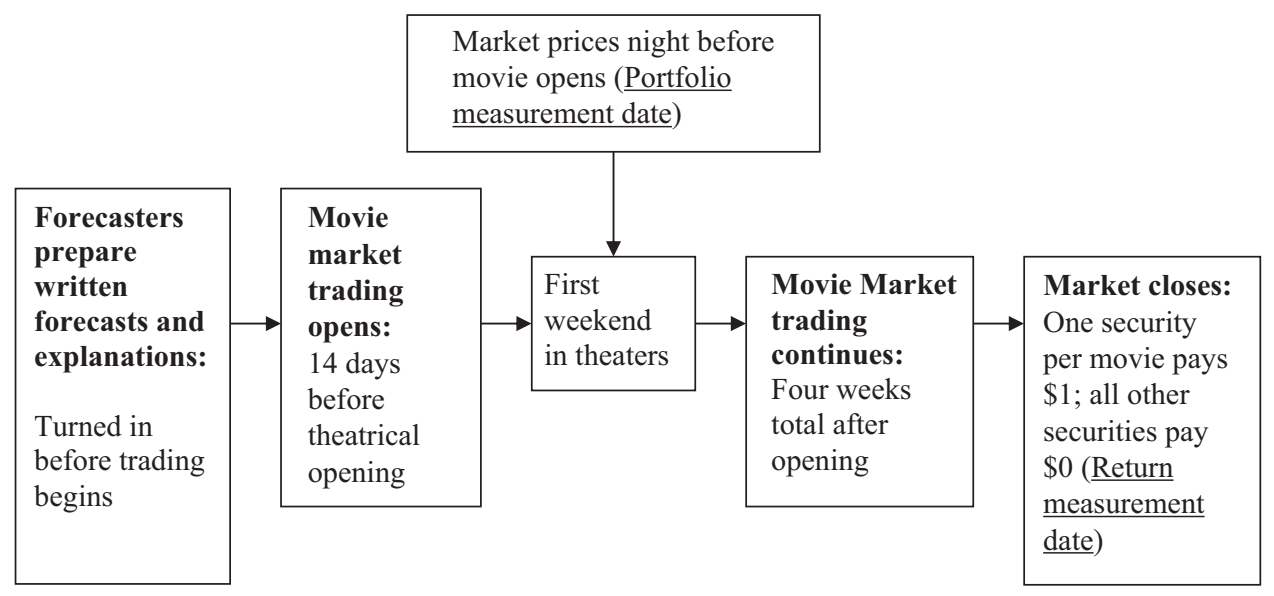


at other web sites, e.g., www.the-numbers.com. After the final 4-week receipts were available, the markets were liquidated. This entails exchanging \$1 for each winning security held by a trader. Nothing is paid for losing securities.

The Portfolio Measurement Date occurs midnight on the Thursday night prior to movie's opening day. We chose this date since it occurs before the introduction of reliable, exogenous information to market. Once a movie opens in theaters, information about box office receipts is readily available from various content providers such as Nielsen/EDI, the-numbers.com, Variety, etc. Prior research (e.g., Krider and Weinberg, 1988; Pennock, Lawrence, Giles and Nielsen, 2001) has shown that information about the performance of the movie in its first weekend creates a highly reliable signal of ultimate 4-week box office performance.

The Return Measurement Date occurs after all liquidation amounts are distributed. This captures how well members of each group performed given a considerable amount of publicly available information during the four weeks of trading after each movie opened in theaters.

\section{MODELS OF INVESTOR PORTFOLIOS AND OUTCOMES}

To determine the effect of the explanation effect on trader holdings, we have to determine their preferred outcomes. Due to the explanation effect, each trader is assumed to prefer the security associated with his or her point forecast (Note that traders did not know how the securities would be defined before trading began). For example, consider a forecaster who predicted that the 1999 movie Sleepy Hollow would earn only $\$ 25$ million in its first four weeks of release. Based only on this forecast, we expect that forecaster would buy and hold more of the SH030L security since it pays $\$ 1$ in the event that the movie makes $\$ 30$ million or less in the specified period. Before the movie opens in theaters, we expect such forecasters to hold a higher proportion of their preferred security in their portfolios than the forecasters who predicted a different outcome as well as the non-forecasters.

All investors started with only cash in their accounts. Therefore, the measured portfolios reflect the sales and purchases of securities among all traders as well as purchases of bundles from securities from the market. We determined the net (or unbalanced) portfolio for each trader by removing all unit bundles (one of each of the securities in the market) since they have an expected value of \$1 and are, therefore, equivalent to cash (Forsythe, Frank, Krishnamurthy and Ross, 1998). Using the security prices at midnight on the night before the movie opened in theaters, we computed the dollar value of each trader's net portfolio. We then computed the proportion of this value accounted for by each of the securities in the market (Forsythe, et al., 1998). To test for the effects of investor preferences on portfolio holdings, we compared the distributions of holdings in the preferred outcome securities by forecasters whose box office prediction fell within the range of a given security and all other traders.

To measure the performance for each investor, we use a metric similar to operating margin (MARGIN). The numerator of MARGIN consists of the 
proceeds of all security sales, bundle sales to the market and proceeds from the liquidation of winning contracts. The denominator consists of payments for bundles to the market and individual securities purchased from other traders. A trader who breaks even has a MARGIN of 1 while one who makes (loses) money has a MARGIN of more (less) than 1. By construction, the MARGIN for the market as a whole is one. This measure accounts for differences in the level of market activity across traders.

In our return calculations, we ignore discounting since the risk-free alternative in this market ( $\$ 1$ bundle) bears a zero interest rate (Bonderenko and Bossaerts, 2000).

\section{RESULTS}

\subsection{PREFERRED OUTCOMES AND INVESTOR PORTFOLIOS}

In order to test for the difference in preferred outcome security holdings across groups, we used a Mann-Whitney test since the data on portfolio holdings is not normally distributed. The unit of analysis was the individual. Our tests compared the group of forecasters whose prediction fell within the range of box office receipts for a given security with all other traders. The average portfolio holdings of these accurate forecasters were compared to those of all other traders in the market. There are 21 such groups across the 4 movie box office prediction markets. Each group is associated with one security in the four markets.

The results are presented in Table $3^{2}$.

Our analysis finds that the proportion of the portfolio in the preferred security was significantly higher $(\mathrm{p}<0.05$ level) for 16 of the 21 forecaster groups $(71 \%)$. If we consider marginally significant differences $(p<0.10)$, the number of groups holding a significantly higher proportion of their preferred security increases to 17 or $81 \%$ of forecaster groups.

These results provide strong support for Hypothesis 1 .

\subsection{FORECASTING REQUIREMENT AND INVESTOR RETURNS}

We separated all traders in each market into one of three groups. Forecasters were split into two groups depending on whether their initial forecast in the investing diary task fell within the range of the winning security (i.e., security

\footnotetext{
2 The sum of the number of forecasters in each group presented in Table 3 does not equal the number of forecasters in Table 2 because, in each market, there were forecasters who did not hold an unbalanced portfolio. These forecasters bought 1 or more bundles and, as such, owned equal amounts of each security on the Portfolio Measurement Date.
} 
Table 3. Preferred Outcome Securities Across Groups

\begin{tabular}{|c|c|c|c|}
\hline \multicolumn{4}{|c|}{ Sleepy Hollow (1999) } \\
\hline Contract & $\begin{array}{l}\text { Mean (Median) Holdings by } \\
\text { Forecasters with Prediction } \\
\text { within Contract Range }\end{array}$ & $\begin{array}{l}\text { Mean (Median) } \\
\text { Holdings of All Other } \\
\text { Traders }\end{array}$ & $\begin{array}{l}\text { Mann-Whitney } \\
\text { U-test Statistic } \\
\text { ( } p \text {-value) }\end{array}$ \\
\hline $\begin{array}{l}\text { SH30L } \\
(\mathrm{N}=7)\end{array}$ & $\begin{array}{l}0.27 \\
(0.32) \\
\end{array}$ & \begin{tabular}{|l|l|}
0.16 \\
$(0.00)$ \\
\end{tabular} & $\begin{array}{l}1.61 \\
(0.11) \\
\end{array}$ \\
\hline $\begin{array}{l}\text { SH50L } \\
(\mathrm{N}=33)\end{array}$ & $\begin{array}{l}0.59 \\
(0.65)\end{array}$ & $\begin{array}{l}0.25 \\
(0.00)\end{array}$ & $\begin{array}{l}4.76 \\
(0.00)\end{array}$ \\
\hline $\begin{array}{l}\text { SH70L } \\
(N=16)\end{array}$ & $\begin{array}{l}0.37 \\
(0.34) \\
\end{array}$ & $\begin{array}{l}0.23 \\
(0.00) \\
\end{array}$ & $\begin{array}{l}2.51 \\
(0.01) \\
\end{array}$ \\
\hline $\begin{array}{l}\mathrm{SH} 90 \mathrm{~L}^{*} \\
(\mathrm{~N}=9)\end{array}$ & $\begin{array}{l}0.14 \\
(0.00)\end{array}$ & $\begin{array}{l}0.17 \\
(0.00)\end{array}$ & $\begin{array}{l}0.67 \\
(0.50)\end{array}$ \\
\hline $\begin{array}{l}\mathrm{SH} 90 \mathrm{H} \\
(\mathrm{N}=5)\end{array}$ & $\begin{array}{l}0.33 \\
(0.39)\end{array}$ & $\begin{array}{l}0.11 \\
(0.00)\end{array}$ & $\begin{array}{l}2.86 \\
(0.00)\end{array}$ \\
\hline \multicolumn{4}{|c|}{ The World is not Enough (1999) } \\
\hline $\begin{array}{l}\text { Contract } \\
\text { (Number of } \\
\text { Forecasters) }\end{array}$ & $\begin{array}{l}\text { Mean (Median) Holdings by } \\
\text { Forecasters with Prediction } \\
\text { within Contract Range }\end{array}$ & $\begin{array}{l}\text { Mean (Median) } \\
\text { Holdings of All Other } \\
\text { Traders }\end{array}$ & $\begin{array}{l}\text { Mann-Whitney } \\
\text { U-test Statistic } \\
\text { ( } p \text {-value) }\end{array}$ \\
\hline $\begin{array}{l}\text { WINE40L } \\
(\mathrm{N}=2)\end{array}$ & $\begin{array}{l}0.27 \\
(0.27) \\
\end{array}$ & $\begin{array}{l}0.11 \\
(0.00) \\
\end{array}$ & $\begin{array}{l}2.46 \\
(0.09) \\
\end{array}$ \\
\hline $\begin{array}{l}\text { WINE60L } \\
(\mathrm{N}=7)\end{array}$ & $\begin{array}{l}0.09 \\
(0.00)\end{array}$ & $\begin{array}{l}0.12 \\
(0.00)\end{array}$ & $\begin{array}{l}0.26 \\
(0.80)\end{array}$ \\
\hline $\begin{array}{l}\text { WINE80L } \\
(N=13)\end{array}$ & $\begin{array}{l}0.30 \\
(0.31)\end{array}$ & $\begin{array}{l}0.14 \\
(0.00)\end{array}$ & $\begin{array}{l}2.69 \\
(0.01)\end{array}$ \\
\hline $\begin{array}{l}\text { WINE100L } \\
(\mathrm{N}=5)\end{array}$ & $\begin{array}{l}0.67 \\
(0.73)\end{array}$ & $\begin{array}{l}0.27 \\
(0.10)\end{array}$ & $\begin{array}{l}3.77 \\
(0.00)\end{array}$ \\
\hline $\begin{array}{l}\text { WINE100H* } \\
(\mathrm{N}=40)\end{array}$ & $\begin{array}{l}0.58 \\
(0.53)\end{array}$ & $\begin{array}{l}0.21 \\
(0.00)\end{array}$ & $\begin{array}{l}5.80 \\
(0.00)\end{array}$ \\
\hline \multicolumn{4}{|c|}{ Harry Potter and the Sorcerer's Stone (2001) } \\
\hline Contract & $\begin{array}{l}\text { Mean (Median) Holdings by } \\
\text { Forecasters with Prediction } \\
\text { within Contract Range }\end{array}$ & $\begin{array}{l}\text { Mean (Median) } \\
\text { Holdings of All Other } \\
\text { Traders }\end{array}$ & $\begin{array}{l}\text { Mann-Whitney } \\
\text { U-test Statistic } \\
\text { ( } p \text {-value) }\end{array}$ \\
\hline $\begin{array}{l}\text { HPS160L } \\
(\mathrm{N}=10)\end{array}$ & $\begin{array}{l}0.30 \\
(0.003) \\
\end{array}$ & $\begin{array}{l}0.06 \\
(0.00) \\
\end{array}$ & $\begin{array}{l}2.13 \\
(0.03) \\
\end{array}$ \\
\hline $\begin{array}{l}\text { HPS180L } \\
(\mathrm{N}=8)\end{array}$ & $\begin{array}{l}0.10 \\
(0.006)\end{array}$ & $\begin{array}{l}0.06 \\
(0.00)\end{array}$ & $\begin{array}{l}2.23 \\
(0.03)\end{array}$ \\
\hline $\begin{array}{l}\text { HPS } 200 L \\
(\mathrm{~N}=15)\end{array}$ & $\begin{array}{l}0.07 \\
(0.005) \\
\end{array}$ & $\begin{array}{l}0.02 \\
(0.00)\end{array}$ & $\begin{array}{l}2.68 \\
(0.01)\end{array}$ \\
\hline $\begin{array}{l}\text { HPS } 220 L \\
(N=6)\end{array}$ & $\begin{array}{l}0.17 \\
(0.11)\end{array}$ & $\begin{array}{l}0.15 \\
(0.00)\end{array}$ & $\begin{array}{l}1.92 \\
(0.06)\end{array}$ \\
\hline $\begin{array}{l}\text { HPS } 240 L \\
(\mathrm{~N}=15)\end{array}$ & $\begin{array}{l}0.20 \\
(0.21)\end{array}$ & $\begin{array}{l}0.15 \\
(0.13)\end{array}$ & $\begin{array}{l}2.20 \\
(0.03)\end{array}$ \\
\hline $\begin{array}{l}\text { HPS240H* } \\
(\mathrm{N}=19)\end{array}$ & $\begin{array}{l}0.72 \\
(0.70)\end{array}$ & $\begin{array}{l}0.46 \\
(0.65)\end{array}$ & $\begin{array}{l}2.74 \\
(0.01)\end{array}$ \\
\hline
\end{tabular}


Table 3. (continued)

\begin{tabular}{|l|l|l|l|}
\hline \multicolumn{2}{|l|}{ Die Another Day (2002) } \\
\hline Contract & $\begin{array}{l}\text { Mean (Median) Holdings by } \\
\text { Forecasters with Prediction } \\
\text { within Contract Range }\end{array}$ & $\begin{array}{l}\text { Mean (Median) } \\
\text { Holdings of All Other } \\
\text { Traders }\end{array}$ & $\begin{array}{l}\text { Mann-Whitney } \\
\text { U-test Statistic } \\
\text { ( } \boldsymbol{p} \text {-value) }\end{array}$ \\
\hline DIE90L & 0.52 & 0.09 & 3.04 \\
$(\mathrm{~N}=3)$ & $(0.29)$ & $(0.00)$ & $(0.00)$ \\
\hline DIE100L & 0.11 & 0.09 & 1.39 \\
$(\mathrm{~N}=11)$ & $(0.07)$ & $(0.00)$ & $(0.17)$ \\
\hline DIE110L & 0.63 & 0.14 & 4.01 \\
$(\mathrm{~N}=10)$ & $(0.72)$ & $(0.00)$ & $(0.00)$ \\
\hline DIE120L & 0.46 & 0.21 & 3.46 \\
$(\mathrm{~N}=17)$ & $(0.36)$ & $(0.00)$ & $(0.00)$ \\
\hline DIE120H* & 0.54 & 0.31 & 2.70 \\
$(\mathrm{~N}=26)$ & $(0.59)$ & $(0.00)$ & $(0.01)$ \\
\hline
\end{tabular}

*denotes winning contract

that paid $\$ 1$ at the end of the market) - accurate forecasters - or whether it did not - inaccurate forecasters. The third group consisted of all non-forecasters.

Like portfolio holdings, the MARGINS of the traders are not normally distributed. Therefore, we used the Kruskal-Wallace test for differences across the three groups of traders. The pair-wise comparisons between the accurate forecasters, inaccurate forecasters and non-forecasters were computed using the Bonferroni correction. The results are presented in Table 4.

The overall test of differences across the three groups of traders revealed significance in three of the four markets at the $p<0.00$ level (The exception was the Sleepy Hollow market). In two of these markets, the returns for accurate forecasters were higher than those of the other two groups. In these two markets (World is not Enough and Harry Potter), the returns of non-forecasters and inaccurate forecasters were not significantly different at the $\mathrm{p}<0.05$ level.

In the Die Another Day market, the returns for non-forecasters were significantly lower $(\mathrm{p}<0.05$ level $)$ than those of the accurate forecasters and non-forecasters. There were no significant differences between these latter two groups (at the $\mathrm{p}<0.05$ level).

The results for the Sleepy Hollow market were unexpected since there were no significant differences between the returns of any pair of groups. In other words, traders with accurate forecasts had no higher returns than those with inaccurate forecasts or non-forecasters. This unusual result may be due to the previous finding (Table 3: SH90L contract) that the group of accurate forecasters, on average, did not hold a higher proportion of their preferred security than other traders did. This is unfortunate for them since, while their portfolios did not show evidence of overconfidence, the preferred security turned out to be the winning contract. 
Table 4. Comparison of Margins Performance by Trader Group

\begin{tabular}{|l|l|l|l|l|}
\hline Movie Market & $\begin{array}{l}\text { Average } \\
\text { (Median) Margin } \\
\text { for Accurate } \\
\text { Forecasters }\end{array}$ & $\begin{array}{l}\text { Average } \\
\text { (Median) Margin } \\
\text { for Inaccurate } \\
\text { Forecasters }\end{array}$ & $\begin{array}{l}\text { Average } \\
\text { (Median) Margin } \\
\text { for } \\
\text { Non-forecasters }\end{array}$ & $\begin{array}{l}\text { Kruskal- } \\
\text { Wallace Test } \\
\text { Statistc } \\
(\boldsymbol{p} \text {-value) }\end{array}$ \\
\hline Sleepy Hollow & $\begin{array}{l}0.57^{\mathrm{a}} \\
(0.21)^{\mathrm{b}}\end{array}$ & $\begin{array}{l}0.66 \\
(0.57)\end{array}$ & $\begin{array}{l}0.74 \\
(0.34)\end{array}$ & $\begin{array}{l}3.07 \\
(0.21)\end{array}$ \\
\hline $\begin{array}{l}\text { The World Is Not } \\
\text { Enough }\end{array}$ & 1.35 & $0.85^{\mathrm{A}}$ & $0.65^{\mathrm{A}}$ & 38.5 \\
$(1.24)$ & $(0.72)$ & $(0.67)$ & $(0.00)$ \\
\hline $\begin{array}{l}\text { Harry Potter and } \\
\text { the Sorcerer's } \\
\text { Stone }\end{array}$ & 1.24 & $0.83^{\mathrm{A}}$ & $0.70^{\mathrm{A}}$ & 20.8 \\
\hline Die Another Day & $(1.18)$ & $(1.00)$ & $(0.96)$ & $(0.00)$ \\
\hline All Markets & $1.11^{\mathrm{A}}$ & 0.59 & $0.86^{\mathrm{A}}$ & 14.6 \\
$(1.09)$ & $(0.63)$ & $0.97)$ & $(0.00)$ \\
\hline
\end{tabular}

${ }^{a}$ Mean

b Median

A indicates no differences at the $p<0.01$ level for a two-tailed Mann-Whitney U-test with Bonferroni correction.

The overall test across all traders in the four markets showed that the returns for the forecasters with accurate predictions were higher than those of the non-forecasters and forecasters with inaccurate traders.

The returns for inaccurate forecasters were lower than those of the nonforecasters in only one the four markets we studied. Thus, we generate little support for Hypothesis 2.

\section{DISCUSSION AND CONCLUSIONS}

In this study, we try to answer a question that no one seems to be asking but should be. How well do the supposed corrections or "cures" for common decision biases that have been proposed in the investing literature actually perform? Some of these books and articles cite academic literature on the source of a given bias. However, what appears to be less common is any empirical support for the advice given on how to reduce or eliminate the focal bias. Given its pernicious nature, we thought hindsight bias would be a particularly relevant place to start.

Clearly, the empirical evidence supporting the use of written materials to eliminate hindsight bias is sound (Davies, 1987). However, our focus was on the unintended consequences of writing down one's investing forecasts and justifications. We focused on the current effects on investing actions and returns rather than the expected future benefits of a reduction in investors' (over) estimates of their wisdom in the past. 
Our results show that the act of writing down a prediction does influence the traders' actions in the market. Traders who completed the investing diary task held a higher than expected proportion of their portfolio in their preferred contract. This is sign of overconfidence predicted by Odean (1998) but to our knowledge, unproven in real money markets. The findings with respect to portfolio holdings are likewise consistent with the predictions of psychological research on the explanation effect. We also note that our results join the few instances we know of where an explanation task results in changes in behavior. Clearly, the changes wrought by justifying one's prediction in writing affect more than memory or subsequent judgments.

This finding also extends our understanding of the impact of the preferences on non-professional investors (Eames, et al., 2006; Hales, 2007; Han and Tan, 2010; Thayer, 2011) in a more realistic setting. In the extant research in this field, a trader's preference for an outcome is randomly assigned. In this study, trader preferences for the different securities resulted from their own efforts to forecast an uncertain future event, clearly a much more likely setting. Second, instead of focusing solely on changes in an investor's perceptions or cognitive processing of new information, our study shows how trader preferences affect the actual buying and selling of real money securities. Adding to the existing stream of research, we find that trader preferences have a significant impact on portfolios. This occurs despite the information available to all traders embedded in the prices of securities in the market. In short, preferences have a significant influence on trader actions even in the presence of monetary incentives that should motivate traders to use all information available to make the best possible decisions.

Our second finding concerns that impact of differences in returns associated with different types of traders. As in the current literature on asymmetric information, our study includes traders whose predictions were accurate as well as those whose predictions were inaccurate. Prior research in a prediction market setting (Goins, et al., 2015) showed that traders with better forecasts have higher returns, which is consistent with prior theoretical models (Grossman and Stiglitz, 1980).

The critical addition in this study is the presence of a pool of traders who were not required to complete the investing diary task. While we do not know what information these traders brought to the market, they serve as a benchmark against which to measure the relative impact of having an accurate forecast versus an inaccurate forecast. This is of interest given the experimental research by Huber (2007) showing that traders with no information can have higher returns than traders with more, albeit incomplete, information about the value of the security being traded. This begets the so-called J-shaped relationship between returns and levels of information. In the case of investing diaries, such a pattern in our markets would suggest that the investing diary task hurt the returns of forecasters with inaccurate predictions to the point of being lower than those who did not, so far as we can tell, "do their investing homework." 
Our results do not support the J-shaped relationship found in Huber's (2007) lab experiments. There are several reasons for this difference. First, there may also have been differences in wealth between the forecasters and non-forecasters. The forecasters generally traded with their provided funds. In contrast, a small number of non-forecasters put a relatively large amount of money at risk in these markets and accounted for a large volume of the trades.

Second, in the lab experiments, one set of traders was provided with no information. The non-forecasters in our markets were self-selected and selffunded. While some prediction market traders may participate for the entertainment value (Wolfers and Zitzewitz, 2004), we surmise that at least some of the non-forecasters had enough confidence in their private information or, perhaps, trading skills to risk their own money in the market. This lack of a truly uninformed control group of traders is one of the trade-offs associated with field studies.

As with any empirical study, there are other limitations to this study. These are small-scale markets and the traders are not investing for retirement. Our forecasters are similar to participants in prior studies (Hales, 2007; Han and Tan, 2010; Thayer, 2011) in that they are graduate business students and the prediction task is unfamiliar. We also know little about the non-forecasters other than they have an academic affiliation.

In conclusion, we show that the actions associated with keeping an investing diary lead to over-confidence as reflected in trader's portfolio choices. With respect to returns, forecasters whose predictions were accurate had better outcomes than other traders. However, those forecasters with inaccurate predictions performed no better and, surprisingly, no worse than non-traders who were not required to complete the investing diary task. Overall, these results do not argue convincingly in favor of or against keeping an investing diary. In the markets we studied, the investing diary was only beneficial to those with accurate forecasts. Unfortunately, investors do not know - ex ante which group they are in.

\section{REFERENCES}

CA Anderson, MR Lepper, and L Ross 'The perseverance of social theories: The role of explanation in the persistence of discredited information' (1980) 39 Journal of Personality and Social Psychology, pp. 1037-1049.

HR Arkes 'The Consequences of the Hindsight Bias in Medical Decision Making' (2013) 22 Current Directions in Psychological Science 5, pp. 356-360.

BM Barber and T Odean 'Online Investors: Do the Slow Die First?' (2002) 15 The Review of Financial Studies 2, pp. 455-488.

N Barberis and R Thaler 'A survey of behavioral finance' in GM Constantinides, M Harris and R Stulz (eds) Handbook of the Economics of Finance (Elsevier Science, 2001). 
G Belsky and T Gilovich Why Smart People Make Big Money Mistakes And How To Correct Them: Lessons From The New Science Of Behavioral Economics (New York, Simon and Schuster, 2000).

JE Berg, FD Nelson and T Rietz 'Prediction Market Accuracy in the Long Run’ (2008) 24 International Journal of Forecasting 2, pp. 283-298.

$\mathrm{B}$ Biais and $\mathrm{M}$ Weber 'Hindsight Bias, Risk Perception and Investment Performance' (2009) 55 Management Science 6, pp. 1018-1029.

$\mathrm{H}$ Blank, V Fischer and E Erdfelder 'Hindsight bias in political elections' (2003) 11 Memory 4-5, pp. 491-504

$\mathrm{G}$ Bodenhausen 'Stereotypic biases in social decision making and memory: testing process models of stereotype use' (1988) 55 Journal of Personality and Social Psychology, pp. 726-737.

O Bondarenko and P Bossaerts 'Expectations and learning in Iowa' (2000) 24 Journal of Banking \& Finance 9, pp. 1535-1555.

B Carey 'That Guy Won? Why We Knew It All Along' (October 29, 2012) New York Times. See https://www.nytimes.com/2012/10/30/health/he-won-theelection-i-knew-it-all-along.html?pagewanted=all.

JJ Christensen-Szalanski and C Fobian-Willham 'The hindsight bias: A metaanalysis' (1991) 48 Organizational Behavior and Human Decision Processes 1, pp. 147-168.

S Constable 'How to Keep an Investment Diary' (May 17, 2016) US News and World Report. See https://money.usnews.com/investing/articles/2016-05-17/ how-to-keep-an-investment-diary.

K Daniel, D Hirshleifer and A Subrahmanyam 'Investor Psychology and Security Market Under- and Overreactions' (1998) 53 Journal of Finance 6, pp. 1839-1886.

MF Davies 'Reduction of hindsight bias by restoration of foresight perspective: Effectiveness of foresight-encoding and hindsight-retrieval strategies' (1987) 40 Organizational Behavior and Human Decision Processes 1, pp. 50-68.

PH Ditto, GD Munro, A Apanovitch, JA Scepansky and LK Lockhart 'Motivated sensitivity to preference-inconsistent information' (1998) 75 Journal of Personality and Social Psychology 1, pp. 53-69.

MJ Eames, SM Glover and JJ Kennedy 'Stock Recommendations as a Source of Bias in Earnings Forecasts' (2006) 18 Behavioral Research in Accounting, pp. 37-51.

K Elkins 'A brief history of the 401(k), which changed how Americans retire' (January 4 2017) CNBC.com. See https://www.cnbc.com/2017/01/04/a-briefhistory-of-the-401k-which-changed-how-americans-retire.html.

E Erdfelder and A Buchner 'Decomposing the hindsight bias: A multinomial processing tree model for separating recollection and reconstruction in hindsight' (1998) 24 Journal of Experimental Psychology: Learning, Memory, and Cognition 2, pp. 387-414

B Fischhoff 'Perceived informativeness of facts' (1977) 3 Journal of Experimental Psychology: Human Perception and Performance, pp. 349-358. 
R Forsythe, F Nelson, GR Neumann and J Wright 'Anatomy of an Experimental Political Stock Market' (1992) 82 American Economic Review, pp. 1142-1161.

R Forsythe, M Frank, V Krishnamurthy and TW Ross 'Markets as Predictors of Election Outcomes: Campaign Events and Judgement Bias in the 1993 UBC Election Stock Market' (1998) 24 Canadian Public Policy 3, pp. 329-351.

S Gervais and T Odean 'Learning to Be Overconfident' (2001) 14 The Review of Financial Studies 1, pp. 1-27.

S Goins, TS Gruca and MC Cipriano 'Private Information, Overconfidence and Trader Returns in Prediction Markets' (2015) 9 Journal of Prediction Markets 3, pp. 1-21.

PA Granhag., LA Strömwall and CM Allwood 'Effects of Reiteration, Hindsight Bias, and Memory on Realism in Eyewitness Confidence' (2000) 14 Applied Cognitive Psychology 14, pp. 397-420.

SJ Grossman and JE Stiglitz 'On the impossibility of informationally efficient markets' (1980) 70 The American Economic Review 3, pp. 393-408.

TS Gruca 'The IEM movie box office market: Integrating marketing and finance using electronic markets' (2000) 22 Journal of Marketing Education 1, pp. 5-14.

J Hales 'Directional Preferences, Information Processing and Investors' Forecasts of Earnings' (2007) 45 Journal of Accounting Research 3, pp. 607-628.

JS Hammersley, K Kadous and AM Magro 'Cognitive and Strategic Components of the Explanation Effect' (1997) 70 Organizational Behavior and Human Decision Processes 2, pp. 149-158.

J Han and H Tan 'Investors' reactions to Management Earnings Guidance: The Joint Effect of Investment Position, News Valence and Guidance Form' (2010) 48 Journal of Accounting Research 1, pp. 81-103.

SS Hawkins and R Hastie 'Hindsight: Biased judgments of past events after the outcomes are known' (1990) 107 Psychological Bulletin 3, pp. 311-327.

$\mathrm{T}$ Hens and A Meier Behavioral finance: the psychology of investing (Switzerland, Credit Suisse, 2015).

G Hoffman 'Investing in shares: a guide for beginners' (June 10, 2015) Money Magazine, See https://www.moneymag.com.au/investing-in-shares-forbeginners.

$\mathrm{J}$ Huber 'J-shaped returns to timing advantage in access to information Experimental evidence and a tentative explanation' (2007) 31 Journal of Economic Dynamics and Control, pp. 2536-2572.

J Huber. M Angerer and M Kirchler 'Experimental asset markets with endogenous choice of costly asymmetric information' (2011) 14 Experimental Economics 2, pp. 223-240.

J Huber, M Kirchler and M Sutter 'Is more information always better? Experimental financial markets with cumulative information' (2008) 65 Journal of Economic Behavior and Organization, pp. 86-104. 
TB Hugh and GD Tracy 'Hindsight bias in medicolegal expert reports' (2002) 176 Medical Journal of Australia, pp. 277-278.

M Kirchler 'Partial knowledge is a dangerous thing - On the value of asymmetric fundamental information in asset markets' (2010) 31 Journal of Economic Psychology 4, pp. 643-658.

RE Krider and CB Weinberg 'Competitive dynamics and the introduction of new products: The motion picture timing game' (1998) 35 Journal of Marketing Research, pp. 1-15.

P Lim, S Stanley and MH Cheong. Value Investing in Asia: The Definitive Guide to Investing in Asia. (New York, John Wiley \& Sons, 2017).

CG Lord, MR Lepper and L Ross 'Biased assimilation and attitude polarization: The effects of prior theories on subsequently considered evidence' (1979) 37 Journal of Personality and Social Psychology, pp. 2098-2110.

J Montie The little book of behavioral investing: how not to be your own worst enemy (New York, John Wiley \& Sons, 2010).

DA Moore and PJ Healy 'The trouble with overconfidence.' (2008) 115 Psychological Review 2, pp. 502-517.

RS Nickerson 'Confirmation bias: a ubiquitous phenomenon in many guises' (1998) 2 Review of General Psychology, pp. 175-220.

$\mathrm{T}$ Odean 'Volume, volatility, price, and profits when all traders are above average' (1998) 53 Journal of Finance, pp. 1887-1934.

DM Pennock, S Lawrence, CL Giles and FA Nielsen 'The power of play: Efficiency and forecast accuracy in web market games' (2002) In NEC Research Institute.

S Pouget, J Sauvagnat and S Villeneuve 'A Mind is a Terrible Thing to Change: Confirmatory Bias in Financial Markets' (2014) Toulouse School of Economics Working Paper.

RF Pohl and W Hell 'No reduction in hindsight bias after complete information and repeated testing' (1996) 67 Organizational Behavior and Human Decision Processes 1, pp. 49-58.

M Rabin and J Schrag 'First impressions matter: a model of confirmatory bias' (1999) 114 Quarterly Journal of Economics, pp. 37-82.

NJ Roese and KD Vohs 'Hindsight Bias' (2012) 7 Perspectives of Psychological Science 5. Pp. 411-426.

MR Lepper, F Strack and J Steinmetz 'Social explanation and social expectation: Effects of real and hypothetical explanations on subjective likelihood' (1977) 35 Journal of Personality and Social Psychology 11, pp. 817-829.

M Ross. and F Sicoly 'Egocentric biases in availability and attribution' In D Kahneman, P Slovic, and A Tversky (Eds.), Judgment under uncertainty: Heuristics and biases. (New York, Oxford University Press, 1982), pp. 129-152.

K Schredelseker 'Anlagestrategie und Informationsnutzen am Aktienmarkt' (1984) 36 Zeitschrift fur Betriebswirtschaftliche Forschung, pp. 44- 59. 
SJ Sherman 'On the Self-Erasing Nature of Errors of Prediction' (1980) 39 Journal of Personality and Social Psychology, pp. 211-221.

SJ Sherman, RB Skov, EE Hervitz and CB Stock 'The effects of explaining hypothetical future events: From possibility to probability to actuality and beyond' (1981) 17 Journal of Experimental Social Psychology, pp. 142-158.

SJ Sherman, KS Zehner, J Johnson and ER Hirt 'Social explanation: The role of timing, set and recall on subjective likelihood estimates' (1983) 44 Journal of Personality and Social Psychology, pp. 1127-1143.

RH Thaler. Misbehaving: The making of behavioral economics (New York, W W Norton \& Co., 2015).

J Thayer 'Determinants of Investors' Information Acquisition: Credibility and Confirmation' (2011) 86 The Accounting Review 1, pp. 1-22.

WF van Raaij 'Consumer Financial Behavior' (2014) 7 Foundations and Trends in Marketing 4, pp 231-351.

J Wolfers and E Zitzewitz 'Prediction Markets' (2004) National Bureau of Economic Research (NBER) See http://www.nber.org/papers/w10504.

G Wood 'The knew-it-all-along effect' (1978) 4 Journal of Experimental Psychology: Human Perception and Performance, pp. 345-353.

J Zweig Your Money and Your Brain: How the New Science of Neuroeconomics Can Help Make You Rich (New York, Simon and Schuster, 2007). 